Research Article

\title{
Degradation of Norfloxacin in an Aqueous Solution by the Nanoscale Zero-Valent Iron-Activated Persulfate Process
}

\author{
Yanchang Zhang, ${ }^{1}$ Lin Zhao $\mathbb{D}^{2},{ }^{2}$ Yongkui Yang, ${ }^{2}$ and Peizhe Sun ${ }^{2}$ \\ ${ }^{1}$ School of Chemical Engineering and Technology, Tianjin University, Tianjin 300350, China \\ ${ }^{2}$ School of Environmental Science and Engineering, Tianjin University, Tianjin 300350, China \\ Correspondence should be addressed to Lin Zhao; zhaolin@tju.edu.cn
}

Received 8 November 2019; Revised 28 January 2020; Accepted 3 February 2020; Published 1 September 2020

Academic Editor: Takuya Tsuzuki

\begin{abstract}
Copyright (c) 2020 Yanchang Zhang et al. This is an open access article distributed under the Creative Commons Attribution License, which permits unrestricted use, distribution, and reproduction in any medium, provided the original work is properly cited.
\end{abstract}

\begin{abstract}
In this study, nanoscale zero-valent iron (nZVI) was synthesized and used to activate persulfate (PS) for the degradation of norfloxacin (NOR). The nZVI/PS system exhibited a high reactivity towards NOR, and the degradation efficiency of NOR $(100 \mathrm{mg} / \mathrm{L})$ reached $93.8 \%$ with $0.1 \mathrm{~g} / \mathrm{L}$ nZVI, $12 \mathrm{mM}$ PS, and an initial $\mathrm{pH}$ of 7.0 within $7 \mathrm{~min}$. The NOR degradation followed a pseudo-first-order kinetic model, and the effects of parameters such as nZVI dosage, PS concentration, initial pH, and temperature were investigated systematically. Overloading of nZVI lowered the degradation efficiency owing to the quenching effect of excessive $\mathrm{Fe}^{2+}$. The higher PS concentration and temperature favored the degradation of NOR. The influence of $\mathrm{pH}$ was not obvious, and the degradation was effective in a wide $\mathrm{pH}$ range. In addition, the radical quenching experiments and electron paramagnetic resonance $(\mathrm{EPR})$ indicated that both sulfate radical $\left(\mathrm{SO}_{4}{ }^{-}\right)$and hydroxyl radical $\left(\mathrm{OH}^{\prime}\right)$ were the dominant radicals in the degradation process, in which the latter played a more important role. Finally, three degradation pathways were proposed based on the result of intermediates identified by liquid chromatography-mass spectrometry. Overall, this study indicated that the nZVI/PS system could provide a promising alternative for NOR wastewater treatment.
\end{abstract}

\section{Introduction}

Nowadays, the existence of antibiotics in the ecosystem, released by pharmaceutical and domestic wastewater, has been recognized as a serious environment problem [1]. Norfloxacin (NOR), a broad-spectrum antibiotic, is one of the most important fluoroquinolone antibiotics widely used in both human and veterinary medicine [2]. In China, more than 500 ton of NOR is used every year [3]. The adsorption of NOR is quite low for both humans and animals, and the majority of NOR (60-70\%) is discharged into the environment through feces and urine [4]. The extensive consumption of NOR and continuous release of effluents containing NOR lead to its bioaccumulation. This may induce antibiotic resistance in bacteria and poses threats to humans' health and the ecological environment [5]. Furthermore, owing to its low degradability and high solubility, it is challenging to remove it from water with conventional technologies [6]. The presence of NOR has been frequently detected in surface water and groundwater from ng/L to $\mu \mathrm{g} / \mathrm{L}$ in many countries around the world [7-9]. Consequently, it is essential to seek effective techniques for the removal of NOR from water. Toward this goal, various treatment methods have been developed, such as adsorption [4], biodegradation [10], and advanced oxidation processes (AOPs) [11].

Among these methods, adsorption is the easiest to apply. However, it is just an immobilization method that does not remove contaminants. In addition, the adsorption ability of an adsorbent is limited for high concentrations of contaminant; furthermore, it takes a long time to achieve adsorption equilibrium [12]. For biodegradation, the adsorption process is complicated, limiting its practical application.

AOPs are regarded as effective treatment for the removal of recalcitrant contaminants [13]. In recent years, persulfatebased in situ chemical oxidation (ISCO) technology has become a promising and effective method for the remediation of organic pollutants [14]. Persulfate ( $\mathrm{PS}, \mathrm{S}_{2} \mathrm{O}_{8}{ }^{2-}$ ) could be an alternative oxidant based on high stability and wide 
$\mathrm{pH}$ operation range [15]. Moreover, PS could be activated via heat [16], UV [17], and transition metals [18], which generated a highly reactive sulfate radical $\left(\mathrm{SO}_{4}{ }^{--}, E_{0}=2.5-3.1 \mathrm{~V}\right)$. Compared with $\mathrm{OH}, \mathrm{SO}_{4}{ }^{-}$is more stable and exhibits a strong oxidative ability in a wide $\mathrm{pH}$ range [19]. Among the transition metal ions, $\mathrm{Fe}^{2+}$ is commonly used to activate PS (Equation (1)) because it is environment friendly and relatively inexpensive [20]. However, a large quantity of $\mathrm{Fe}^{2+}$ is needed in the process owing to the conversion of $\mathrm{Fe}^{2+}$ to $\mathrm{Fe}^{3+}$, and $\mathrm{Fe}^{2+}$ cannot be easily regenerated. The treatment should be performed under acidic conditions to avoid the precipitation of iron at high $\mathrm{pH}$ values. Moreover, the $\mathrm{SO}_{4}{ }^{--}$ could be scavenged at high concentrations of $\mathrm{Fe}^{2+}$ [21]. To overcome these drawbacks, nanoscale zero-valent iron (nZVI) has been employed as an efficient activator of PS owing to its high reactivity. nZVI is the most commonly used nanomaterial for wastewater and underground remediation owing to its reduction potential and high reactivity towards a broad range of contaminants $[22,23]$. nZVI could release $\mathrm{Fe}^{2+}$ slowly to activate PS (Equations (2)-(4)). Furthermore, the recycling of $\mathrm{Fe}^{3+} / \mathrm{Fe}^{0}$ on the nZVI surface could keep the concentration of $\mathrm{Fe}^{2+}$ stable in the solution and reduce the precipitation of iron hydroxides [24, 25]. Previous studies have reported that $\mathrm{nZVI} / \mathrm{PS}$ process could degrade a wide range of contaminants [26-28].

$$
\begin{aligned}
& \mathrm{Fe}^{2+}+\mathrm{S}_{2} \mathrm{O}_{8}^{2-} \longrightarrow \mathrm{Fe}^{2+}+\mathrm{SO}_{4}^{2-}+\mathrm{SO}_{4}^{--} \\
& \mathrm{Fe}^{0}+2 \mathrm{H}_{2} \mathrm{O} \longrightarrow \mathrm{Fe}^{2+}+2 \mathrm{OH}^{-}+\mathrm{H}_{2} \\
& 2 \mathrm{Fe}^{0}+\mathrm{O}_{2}+2 \mathrm{H}_{2} \mathrm{O} \longrightarrow 2 \mathrm{Fe}^{2+}+4 \mathrm{OH}^{-} \\
& \mathrm{Fe}^{0}+2 \mathrm{Fe}^{3+} \longrightarrow 3 \mathrm{Fe}^{2+}
\end{aligned}
$$

Previously, Deng et al. found that $10 \mathrm{mg} / \mathrm{L}$ NOR was completely eliminated within $5 \mathrm{~min}$ in the nanoscale zerovalent copper-activated PS process [29]. Compared with $\mathrm{Cu}^{0}, \mathrm{Fe}^{0}$ exhibits a higher reactivity and may remove NOR even at low concentrations. Moreover, unlike $\mathrm{Cu}$, which is a heavy toxic metal and could cause adverse effects in aquatic ecosystems, Fe is not so hazardous to the environment [30]. To the best of our knowledge, the use of Fe to remove NOR in aqueous solutions has not been reported. Hence, the study on $\mathrm{nZVI} / \mathrm{PS}$ systems for the degradation of NOR is of great importance. Therefore, the objectives of this study were to (1) investigate the effectiveness of NOR degradation in the nZVI/PS system, (2) evaluate different parameters of the NOR degradation, (3) determine the oxidizing radical species, and (4) propose a possible mechanism and pathway of the reaction.

\section{Materials and Methods}

2.1. Chemicals. Norfloxacin (NOR), ferrous sulfate heptahydrate $\left(\mathrm{FeSO}_{4} \cdot 7 \mathrm{H}_{2} \mathrm{O}\right)$, sodium borohydride $\left(\mathrm{NaBH}_{4}\right)$, sodium persulfate $\left(\mathrm{Na}_{2} \mathrm{~S}_{2} \mathrm{O}_{8}\right)$, 5,5-dimethyl-1-pyrroline-N-oxide (DMPO), sodium thiosulfate $\left(\mathrm{Na}_{2} \mathrm{~S}_{2} \mathrm{O}_{3}\right)$, methanol $(\mathrm{MeOH})$, and tert-butanol (TBA) were obtained from Aladdin Reagents Co. Ltd. (Shanghai, China). All the chemicals in this study were of analytical grade and used without further purification. Milli-Q water (18.2 M $\Omega$ ) was used throughout this study.

2.2. Synthesis of $n Z V I$. The nZVI particles were prepared using the liquid-phase reduction method [31-33]. Briefly, $4.94 \mathrm{~g} \mathrm{FeSO}_{4} \cdot 7 \mathrm{H}_{2} \mathrm{O}$ was dissolved in a $100 \mathrm{~mL}$ water-ethanol solution $(7: 3, v / v)$, and $100 \mathrm{~mL}$ of a $0.36 \mathrm{M} \mathrm{NaBH}_{4}$ solution was added dropwise with vigorous stirring. The entire process progressed under a nitrogen atmosphere. After nZVI particles were generated, they were isolated by vacuum filtration and rinsed three times with ethanol and distilled water. Finally, the nZVI particles were dried in a vacuum oven overnight and stored in an airtight container for further use. The process could be described according to Equation (5) [34].

$$
2 \mathrm{Fe}^{2+}+\mathrm{BH}_{4}^{-}+2 \mathrm{H}_{2} \mathrm{O} \longrightarrow 2 \mathrm{Fe}+\mathrm{BO}_{2}^{-}+2 \mathrm{H}_{2}+4 \mathrm{H}^{+}
$$

2.3. Characterization. The morphology of the nZVI particles was observed by transmission electron microscopy (TEM, JEM-1200EX). The surface structure composition was studied by X-ray diffraction (XRD, D8 advanced diffractometer, Bruker) with $\mathrm{Cu} / \mathrm{K} \alpha$ radiation $(\lambda=1.5406 \AA)$ at $45 \mathrm{kV}$. $\mathrm{X}$-ray photoelectron spectroscopy (XPS, ESCALAB 250Xi, Thermo Corporation) was used to determine the elemental composition of nZVI. The specific surface area was determined by using ASAP 2460 (Micromeritics).

2.4. Batch Experiments. All batch experiments were conducted in $300 \mathrm{~mL}$ conical flasks at ambient temperature $\left(25 \pm 1^{\circ} \mathrm{C}\right)$. For each experiment, $250 \mathrm{~mL}$ of $100 \mathrm{mg} / \mathrm{L} \mathrm{NOR}$ solution was transferred into the flasks; then, predetermined amounts of nZVI and PS were added into the solution to initiate the reaction. The flasks were covered with aluminum foil to prevent light from potentially influencing the reaction and placed in a water bath with magnetic stirring at a speed of $300 \mathrm{r} / \mathrm{min}$. The $\mathrm{pH}$ of the NOR solution was adjusted with $0.1 \mathrm{M} \mathrm{HCl}$ or $\mathrm{NaOH}$. At regular intervals, $1.5 \mathrm{~mL}$ of the solution sample was withdrawn and passed through a $0.22 \mu \mathrm{m}$ membrane filter. Then, sodium thiosulfate was added to the withdrawn sample immediately to quench the reaction for further analysis. The effects of nZVI dosage $(0.025,0.05$, $0.10,0.20$, and $0.30 \mathrm{~g} / \mathrm{L})$, PS concentration $(3,6,12$, and $24 \mathrm{mM})$, initial $\mathrm{pH}(3.0,4.5,7.0,9.5$, and 11.0), and temperature $\left(15,25,35\right.$, and $\left.45^{\circ} \mathrm{C}\right)$ on the degradation of NOR were investigated. All these experiments were performed in duplicate.

2.5. Analytical Methods. The concentration of NOR was determined by a high-performance liquid chromatography (LC2030c, Shimadzu) system equipped with an C18 column $(150 \mathrm{~mm} \times 4.6 \mathrm{~mm}, 5 \mu \mathrm{m})$ at a wavelength of $278 \mathrm{~nm}$. The mobile phase consisted of methanol and a $0.1 \mathrm{wt} \%$ phosphoric acid solution (25:75), and the flow rate was kept at $1.0 \mathrm{~mL} / \mathrm{min}$. The concentration of dissolved iron was measured using 1,10-phenanthroline with a UVspectrophotometer (D6000, Hach Company) at $510 \mathrm{~nm}$ [35]. The PS concentration was determined by a spectrometric method [36]. The radicals were analyzed with an electron paramagnetic resonance (EPR) spectrometer (A300 microx, 


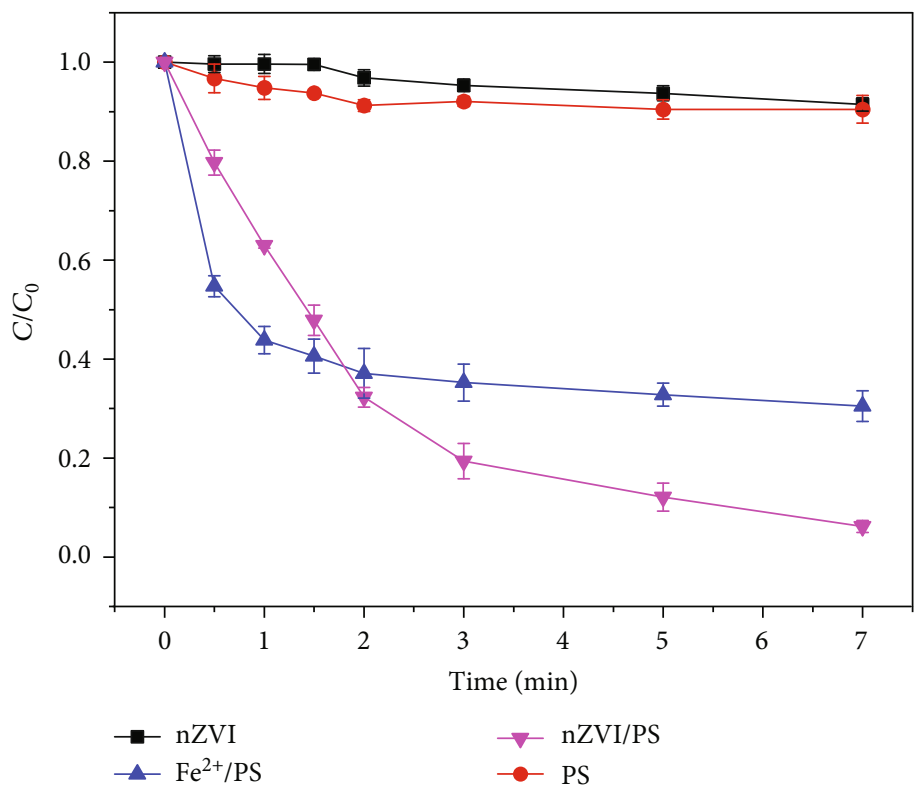

Figure 1: Comparison of NOR degradation in different systems. Operating conditions: $C_{0}=100 \mathrm{mg} / \mathrm{L}, \mathrm{pH}=7.0, T=25^{\circ} \mathrm{C},[\mathrm{PS}]_{0}=12 \mathrm{mM}$, and $\mathrm{Fe}^{2+}=\mathrm{nZVI}=0.1 \mathrm{~g} / \mathrm{L}$.

Bruker Corporation) according to the method proposed by Hussain et al. [34]. The mineralization of NOR was determined by a Total Organic Carbon (TOC) analyzer (TOC-L, Shimadzu). The chemical oxygen demand (COD) was measured using a COD tester (DRB200, Hach, USA). The $\mathrm{pH}$ was measured by a Mettler-Toledo $\mathrm{pH}$ meter. The intermediate products of NOR were analyzed by an LC-MS (TSQ Quantum Ultra, Thermo Scientific) equipped with an Ultimate XB-C18 column $(3 \mu \mathrm{m}, 2.1 \mathrm{~mm} \times 100 \mathrm{~mm})$. The MS analysis was operated in the positive ionization mode using an electrospray ion source, and a mixture of $0.1 \%$ formic acid in ultrapure water and acetonitrile $(70: 30, v / v)$ was used as the mobile phase.

\section{Results and Discussion}

3.1. Characterization of $n Z V I-B C$. The TEM images (Fig. $\mathrm{S} 1(\mathrm{a})$ ) revealed that $\mathrm{nZVI}$ particles had a roughly global morphology and aggregated to a chain-like structure owing to the magnetic interactions [37]. The size of nZVI particles varied between $50 \mathrm{~nm}$ and $100 \mathrm{~nm}$. The BET surface area of $\mathrm{nZVI}$ was $5.92 \mathrm{~m}^{2} / \mathrm{g}$. The XRD pattern (Fig. S1(b)) demonstrated that nZVI particles were sufficiently crystallized. The significant peak at $44.7^{\circ}$ was attributed to the presence of $\mathrm{Fe}^{0}$ [38], and no other obvious peaks were observed. The XPS patterns of nZVI (Fig. S1(c)) also illustrated the presence of $\mathrm{Fe}^{0}$ [39], and some iron oxides had formed on the surface of the nZVI particles [40]. All these results clearly demonstrated that nZVI was synthesized successfully.

3.2. Comparison of NOR Degradation in Different Systems. A series of control experiments were carried out to evaluate the effect of different nZVI/PS system compositions on NOR degradation. Figure 1 shows the NOR degradation perfor- mances in nZVI alone, PS alone, $\mathrm{Fe}^{2+} / \mathrm{PS}$, and nZVI/PS systems under the same conditions. The removal of NOR was minimal in the nZVI system, and the observations were consistent with the report that NOR is resistant to nZVI treatment [41]. A low degree of degradation (9.5\%) was observed in the PS system owing to the limited oxidation ability of PS $\left(E_{0}=2.01 \mathrm{~V}\right)$ [29]. The removal efficiency of NOR was $69.5 \%$ in the $\mathrm{Fe}^{2+} / \mathrm{PS}$ system after $7 \mathrm{~min}$. The degradation of NOR was rapid at the beginning but remained remarkably suppressed after $1 \mathrm{~min}$ to the scavenging effect of $\mathrm{Fe}^{2+}[24]$. By contrast, the application of nZVI significantly enhanced the activation of PS, and more than $90 \%$ of NOR was removed in $7 \mathrm{~min}$. The results indicated that $\mathrm{nZVI}$ was a good source of $\mathrm{Fe}^{2+}$, which can activate PS effectively to generate $\mathrm{SO}_{4}{ }^{--}$[42], thus enhancing the degradation of NOR.

The variations in dissolved iron and PS concentrations in the nZVI/PS system were investigated. As shown in Figure 2(a), the concentration of $\mathrm{Fe}^{2+}$ first increased rapidly and then decreased to a low concentration in the reaction time, which was well in line with the consumption of PS. $\mathrm{Fe}^{2+}$ was an important activator for PS, and it was quickly oxidized to $\mathrm{Fe}^{3+}$ after reacting with PS. The increase in $\mathrm{Fe}^{2+}$ led to a fast decomposition of PS in the first stage. However, according to Al-Shamsi and Thomson, the reactivity of nZVI particles is inhibited after they make contact with PS because of the passivation of nZVI [43]. Therefore, a downtrend for $\mathrm{Fe}^{2+}$ concentration was observed owing to the higher consumption rate than release rate of $\mathrm{Fe}^{2+} . \mathrm{Fe}^{3+}$ accumulated and increased gradually from 0 to $90.6 \mathrm{mg} / \mathrm{L}$, as $\mathrm{Fe}^{2+}$ was continuously released and reacted with PS. On the other hand, the total dissolved iron concentration was closed to the initial addition of nZVI, which indicated that most of the nZVI was converted to $\mathrm{Fe}^{3+}$ after 


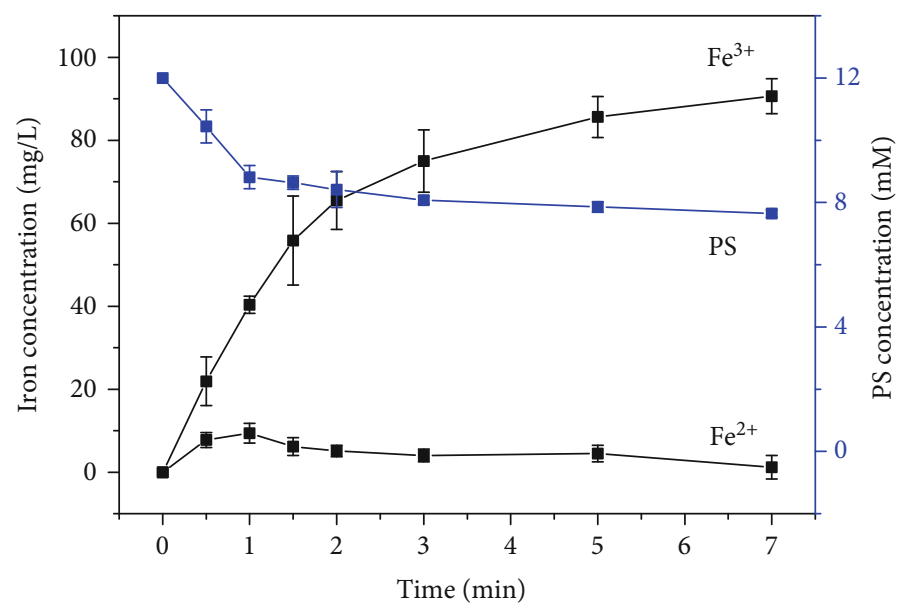

$$
\rightarrow-\mathrm{NOR}
$$

(a)

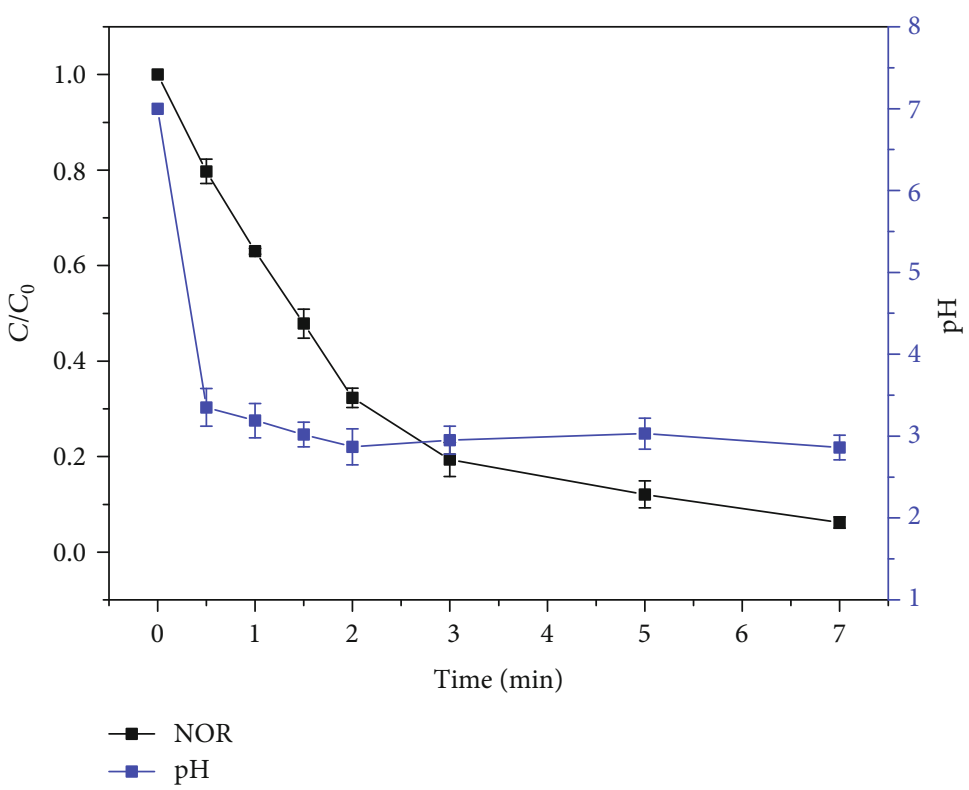

(b)

FIGURE 2: The variation of dissolved iron and PS concentration (a) and $\mathrm{pH}(\mathrm{b})$ in the nZVI/PS system. Operating conditions: $C_{0}=100 \mathrm{mg} / \mathrm{L}$, $\mathrm{pH}=7.0, T=25^{\circ} \mathrm{C},[\mathrm{PS}]_{0}=12 \mathrm{mM}$, and $\mathrm{nZVI}=0.1 \mathrm{~g} / \mathrm{L}$.

the reaction. The change in PS decomposition was attributed to the passivation and depletion of nZVI [21].

The variations in $\mathrm{pH}$ during the degradation process were also measured (Figure 2(b)). The $\mathrm{pH}$ decreased rapidly in the first $30 \mathrm{~s}$ and then maintained a stable value. The obvious decline of the $\mathrm{pH}$ was attributed to the generation of $\mathrm{H}^{+}$and is discussed in Section 3.3.3. Acid conditions favored generation of $\mathrm{Fe}^{2+}$; thus, a high degradation efficiency and rate were obtained in the nZVI/PS system.

The mineralization degree of NOR in the nZVI/PS system was also evaluated, and the result is presented in
Fig. S2. The TOC of NOR decreased slowly in the reaction time, and mineralization of NOR was $15.8 \%$, indicating that most of the NOR was transformed into intermediate products, a small portion of which was then mineralized to $\mathrm{CO}_{2}$ and $\mathrm{H}_{2} \mathrm{O}$. Similar mineralization results were also obtained in the nanoscale zero-valent copper-activated PS process (21.37\%) [29] and peroxymonosulfate (PMS) activation process $(18 \%)$ for NOR degradation [44]. The low TOC removal may be attributed to the generation of intermediates, which may be more difficult to degrade than NOR, and NOR could not be completely mineralized within $7 \mathrm{~min}$ [44]. 
TABLE 1: Data on the NOR degradation in the nZVI-BC/PS system with a pseudo-first-order kinetic model.

\begin{tabular}{lcc}
\hline Conditions & $k_{\mathrm{obs}}\left(\mathrm{min}^{-1}\right)$ & $R^{2}$ \\
\hline nZVI-BC dosage $(\mathrm{g} / \mathrm{L})$ & & \\
0.025 & 0.134 & 0.970 \\
0.05 & 0.170 & 0.984 \\
0.1 & 0.458 & 0.945 \\
0.2 & 0.733 & 0.927 \\
0.3 & 0.436 & 0.958 \\
PS concentration $(\mathrm{mM})$ & & \\
3 & 0.168 & 0.979 \\
6 & 0.270 & 0.983 \\
12 & 0.453 & 0.954 \\
24 & 0.539 & 0.953 \\
$\mathrm{pH}$ & & \\
3.0 & 0.736 & 0.951 \\
4.5 & 0.480 & 0.942 \\
7.0 & 0.453 & 0.954 \\
9.5 & 0.344 & 0.909 \\
11.0 & 0.203 & 0.928 \\
Temperature $\left({ }^{\circ} \mathrm{C}\right)$ & & 0.928 \\
15 & 0.211 & 0.953 \\
25 & 0.453 & \\
35 & 0.676 & \\
45 & 1.202 & \\
\hline
\end{tabular}

\subsection{Influence of Parameters on NOR Degradation}

3.3.1. Effect of nZVI Dosage. The pseudo-first-order kinetic model was used to describe the degradation process of NOR in the nZVI/PS system:

$$
\ln \frac{C_{t}}{C_{0}}=-k_{\mathrm{obs}} t
$$

where $C_{0}(\mathrm{mg} / \mathrm{L})$ was the initial concentration of NOR, $C_{t}$ $(\mathrm{mg} / \mathrm{L})$ was the concentration of NOR at time $t(\mathrm{~min})$, and $k_{\text {obs }}$ was the observed pseudo-first-order rate constant $\left(\mathrm{min}^{-1}\right)$. All the $k_{\mathrm{obs}}$ in this study are summarized in Table 1.

The catalytic activity of different nZVI dosages was investigated, and the results are presented in Figure 3. When $0.025 \mathrm{~g} / \mathrm{L}$ of nZVI was used, about $57.8 \%$ of NOR was degraded within $7 \mathrm{~min}$. The degradation efficiency reached $99.1 \%$ as the dosage was increased to $0.2 \mathrm{~g} / \mathrm{L}$. The reaction rate constant also increased from 0.134 to $0.733 \mathrm{~min}^{-1}$, as the nZVI dosage was increased from 0.025 to $0.2 \mathrm{~g} / \mathrm{L}$. The results indicated that the NOR degradation was significantly influenced by the nZVI dosage. In the nZVI/PS system, the available $\mathrm{Fe}^{2+}$ released from nZVI played a crucial role in the activation of PS and formation of $\mathrm{SO}_{4}{ }^{-}[24,25]$. The number of active sites increased with an increase in the ZVI dose within the range of $0.025-0.2 \mathrm{~g} / \mathrm{L}$, which accelerated the reaction

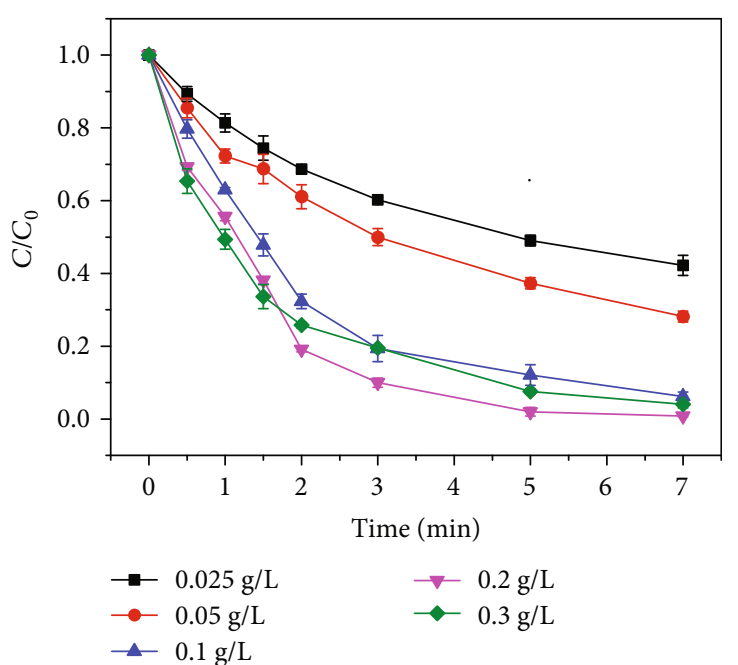

FIgURE 3: Effects of nZVI dosage on NOR degradation in the nZVI/PS system. Operating conditions: $C_{0}=100 \mathrm{mg} / \mathrm{L}, \mathrm{pH}=7.0$, $T=25^{\circ} \mathrm{C}$, and $[\mathrm{PS}]_{0}=12 \mathrm{mM}$.

with PS and increased the production of $\mathrm{SO}_{4}{ }^{-{ }^{-}}$, thereby improving the degradation efficiency and reaction rate [45]. However, the degradation efficiency and reaction rate constant decreased to $96.0 \%$ and $0.436 \mathrm{~min}^{-1}$, when the dosage further increased to $0.3 \mathrm{~g} / \mathrm{L}$. The results were attributed to the generation of excess $\mathrm{Fe}^{2+}$, which induced the scavenging effect of $\mathrm{SO}_{4}{ }^{--}$(Equation (7)) [21]; the consumption of $\mathrm{SO}_{4}{ }^{--}$originally for degradation, therefore, hindered the degradation of NOR. The reaction occurred too quickly for the degradation process to be explored when $0.2 \mathrm{~g} / \mathrm{L}$ of nZVI was added. Consequently, a dosage of $0.1 \mathrm{~g} / \mathrm{L}$ was used in this study owing to its high degradation efficiency.

$$
\mathrm{Fe}^{2+}+\mathrm{SO}_{4}^{--} \longrightarrow \mathrm{Fe}^{3+}+\mathrm{SO}_{4}^{2-}
$$

3.3.2. Effect of PS Concentration. The effect of PS concentration on NOR degradation was investigated with a fixed nZVI dosage. Figure 4 shows that the rate constant increased from 0.168 to $0.539 \mathrm{~min}^{-1}$ when the PS concentration increased from 3 to $24 \mathrm{mM}$. The degradation efficiency also increased from $71.2 \%$ to $98.8 \%$ in the range of 3-24 mM. This was expected because PS was the only source of $\mathrm{SO}_{4}^{--}$, and more $\mathrm{SO}_{4}{ }^{--}$could be generated at a higher PS concentration [46]. When the nZVI dosage was fixed, the amount of $\mathrm{SO}_{4}{ }^{--}$was insufficient for NOR degradation at a low PS concentration. With increasing PS concentration, more PS molecules could make contact and react with nZVI, resulting in a higher production of $\mathrm{SO}_{4}^{--}$and increased NOR degradation. However, $\mathrm{SO}_{4}{ }^{--}$ could react with itself and PS according to Equations (8) and (9), causing a slight increase in $k_{\mathrm{obs}}$ (0.453 and $0.539 \mathrm{~min}^{-1}$ ) when the PS concentration increased from 12 to $24 \mathrm{mM}$. For the $24 \mathrm{mM}$ system, the degradation efficiency increased slightly from $93.8 \%$ to 98.1 with a low PS consumption (23.7\%). In view of economic efficiency, 


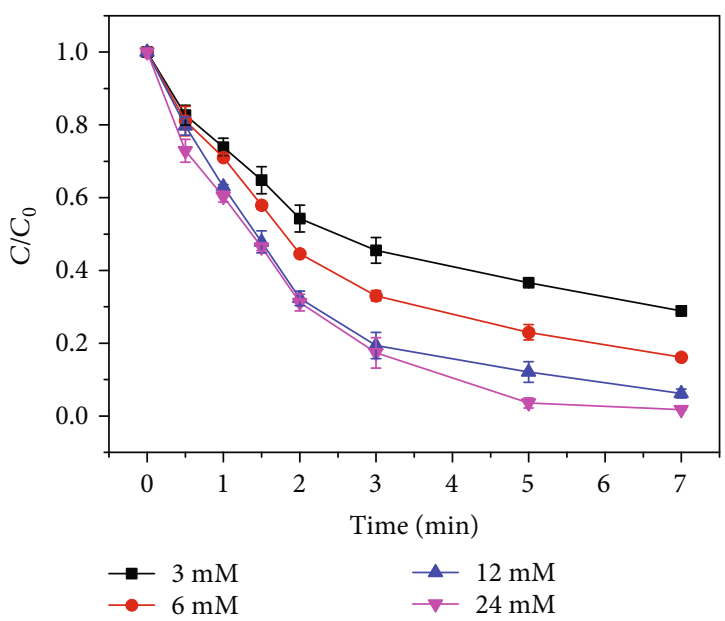

Figure 4: Effects of PS concentration on NOR degradation in the nZVI/PS system. Operating conditions: $C_{0}=100 \mathrm{mg} / \mathrm{L}, \mathrm{pH}=7.0$, $T=25^{\circ} \mathrm{C}$, and $\mathrm{nZVI}=0.1 \mathrm{~g} / \mathrm{L}$.

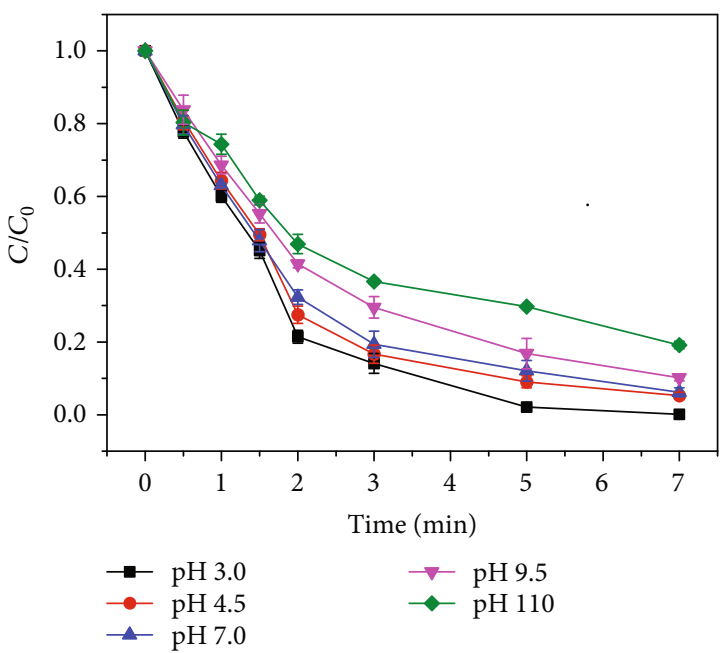

FIGURE 5: Effects of initial $\mathrm{pH}$ on NOR degradation in the nZVI/PS system. Operating conditions: $C_{0}=100 \mathrm{mg} / \mathrm{L}, T=25^{\circ} \mathrm{C},[\mathrm{PS}]_{0}=12$ $\mathrm{mM}$, and $\mathrm{nZVI}=0.1 \mathrm{~g} / \mathrm{L}$.

$12 \mathrm{mM}$ was chosen as the optimum PS concentration for NOR degradation in the experiments.

$$
\begin{gathered}
\mathrm{SO}_{4}^{--}+\mathrm{SO}_{4}^{--} \longrightarrow \mathrm{S}_{2} \mathrm{O}_{8}^{2-} \\
\mathrm{SO}_{4}^{--}+\mathrm{S}_{2} \mathrm{O}_{8}^{2-} \longrightarrow \mathrm{SO}_{4}^{2-}+\mathrm{S}_{2} \mathrm{O}_{8}^{--}
\end{gathered}
$$

3.3.3. Effect of Initial $p H$. The $\mathrm{pH}$ was regarded as an important factor in the iron-mediated and PS activation reaction $[47,48]$. Figure 5 shows that the initial $\mathrm{pH}$ and the acidic conditions favored the degradation of NOR. It can be seen that NOR could be effectively degraded at $\mathrm{pH}<7$, and the degradation was slightly retarded at pH $9.5(89.9 \%)$ and $11.0(80.8 \%)$ within $7 \mathrm{~min}$. The reaction rate constant also decreased from 0.736 to $0.203 \mathrm{~min}^{-}$ ${ }^{1}$ with the rise in $\mathrm{pH}$ from 3.0 to 11.0 . The corrosion of $\mathrm{Fe}^{0}$ could be accelerated at a lower $\mathrm{pH}$ [49], which pro-
TABLE 2: The pH change in the nZVI, PS, and nZVI/PS systems.

\begin{tabular}{lcc}
\hline System & Initial $\mathrm{pH}$ & Final $\mathrm{pH}$ \\
\hline $\mathrm{nZVI}$ & 7.0 & 8.3 \\
\hline PS & 7.0 & 6.5 \\
\hline & 3.0 & 2.5 \\
& 4.5 & 2.7 \\
$\mathrm{nZVI} / \mathrm{PS}$ & 7.0 & 2.8 \\
& 9.5 & 3.1 \\
& 11.0 & 3.6 \\
\hline
\end{tabular}

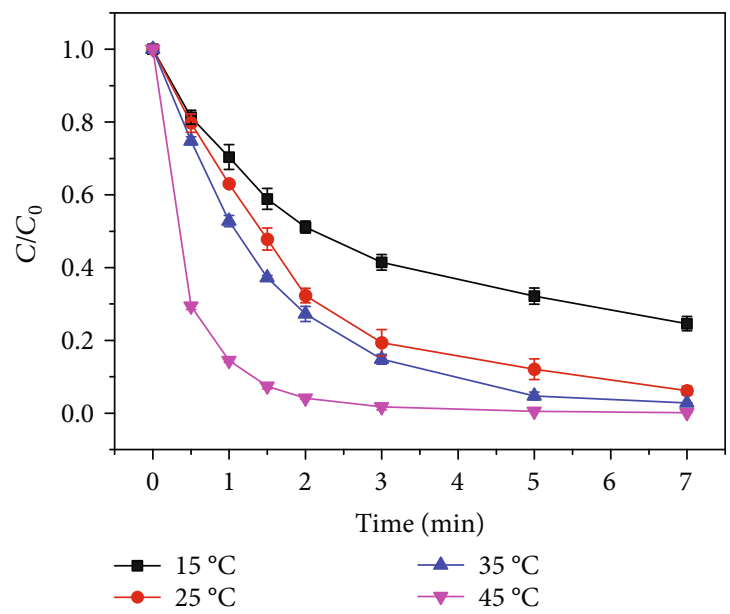

FIGURE 6: Effects of temperature on NOR degradation in the nZVI/PS system. Operating conditions: $C_{0}=100 \mathrm{mg} / \mathrm{L},[\mathrm{PS}]_{0}=12$ $\mathrm{mM}$, and $\mathrm{nZVI}=0.1 \mathrm{~g} / \mathrm{L}$.

duced more $\mathrm{Fe}^{2+}$ that was responsible for the generation of $\mathrm{SO}_{4}{ }^{--}$. However, the dissolved $\mathrm{Fe}^{2+}$ tended to form iron hydroxides under alkaline conditions. The hydroxides were deposited on the surface of nZVI and inhibited further reactions. Therefore, NOR degradation was suppressed under alkaline conditions especially at a $\mathrm{pH}$ of 11.0.

The final $\mathrm{pH}$ values of different experiments are shown in Table 2. The solutions became acidic $(\mathrm{pH}<4.0)$ within 10 min of adding nZVI. As a comparison, PS alone had a little effect on $\mathrm{pH}$, resulting in a slight $\mathrm{pH}$ decrease (7.0 to 5.8) [50]. In the nZVI system, the corrosion of $\mathrm{Fe}^{0}$ would consume $\mathrm{H}^{+}$ions, which resulted in an increase in the $\mathrm{pH}$ value to 8.5. The decrease in $\mathrm{pH}$ in the nZVI/PS system could be attributed to the following: (1) $\mathrm{SO}_{4}{ }^{--}$reacted with $\mathrm{H}_{2} \mathrm{O}$ or $\mathrm{OH}^{-}$, which led to the formation of $\mathrm{H}^{+}$or the consumption of $\mathrm{OH}^{-}$(Equations (10) and (11)) [51]; (2) the hydrolysis of PS generated $\mathrm{H}^{+}$(Equations (12) and (13)) [34]; and (3) some short-chain organic acids (e.g., formic acid, lactic acid, acetic acid, and oxalic acid) were produced in the degradation process of $\mathrm{NOR}$, leading to a release in $\mathrm{H}^{+}[52,53]$. All these facilitate the corrosion of $\mathrm{Fe}^{0}$ and thus enhance the degradation of NOR [54]. As reported, PS can be activated to generate $\mathrm{SO}_{4}{ }^{--}$even at a $\mathrm{pH}$ of 12 [55]. Therefore, when the $\mathrm{pH}$ was higher than 8.5 , the reaction of $\mathrm{SO}_{4}{ }^{--}$with $\mathrm{H}_{2} \mathrm{O}$ 


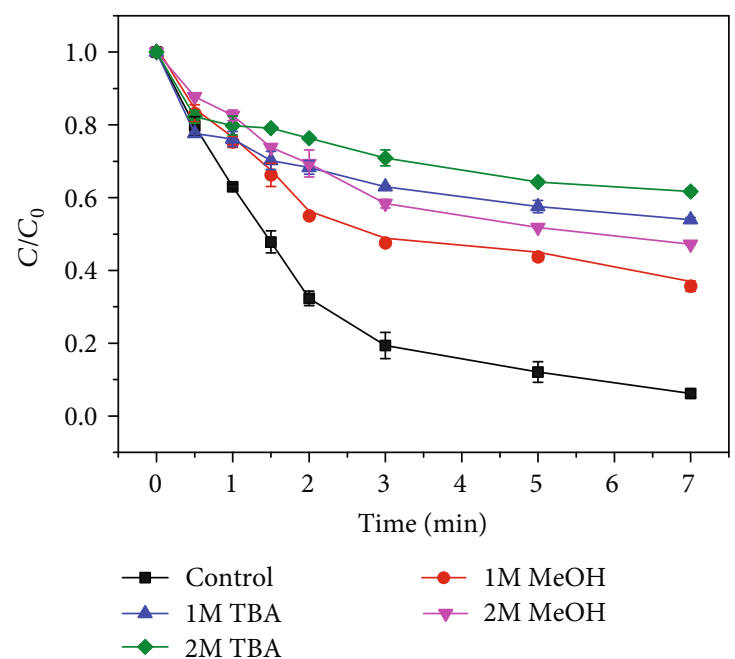

(a)

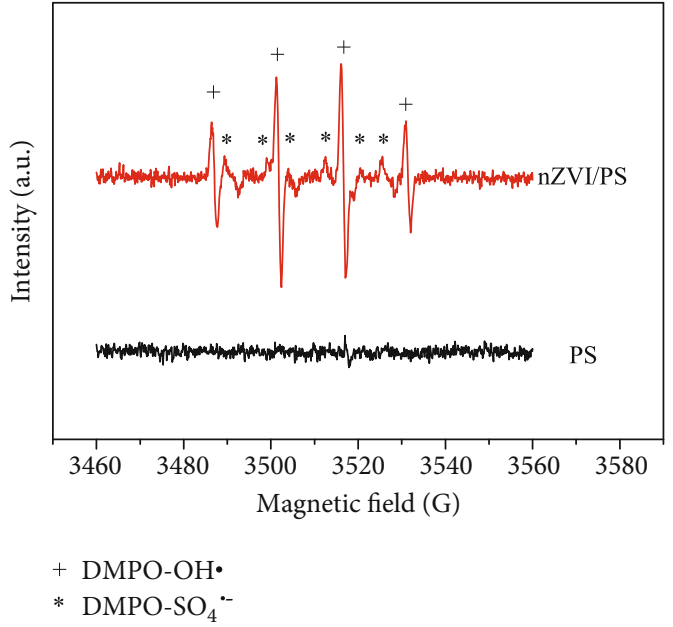

(b)

FIGURE 7: Effect of different radical scavengers (a) and EPR spectra of $\mathrm{SO}_{4}{ }^{-} / \mathrm{OH}$ radical adducts (b) in the nZVI/PS system. Operating conditions: $C_{0}=100 \mathrm{mg} / \mathrm{L}, \mathrm{pH}=7.0, T=25^{\circ} \mathrm{C},[\mathrm{PS}]_{0}=12 \mathrm{mM}$, and $\mathrm{nZVI}=0.1 \mathrm{~g} / \mathrm{L}$.

(Equation (11)) $\left(k=6.5 \times 10^{7} \mathrm{M}^{-1} \mathrm{~s}^{-1}\right)$ decreased the $\mathrm{pH}$ value and reduced the inhibiting effect of iron precipitation, which had a positive effect on the degradation of NOR [56]. The degradation efficiency was not significantly influenced by the initial $\mathrm{pH}$ and reached $80.8 \%$ when the $\mathrm{pH}$ was 11.0 . The high degradation efficiency indicated that NOR could be degraded over a wide $\mathrm{pH}$ range in the nZVI/PS system.

$$
\begin{aligned}
& \text { All pHs : } \mathrm{SO}_{4}^{--}+\mathrm{H}_{2} \mathrm{O} \longrightarrow \mathrm{SO}_{4}^{2-}+\mathrm{OH}^{-}+\mathrm{H}^{+} \\
& \text {Alkaline } \mathrm{pH}: \mathrm{SO}_{4}^{--}+\mathrm{OH}^{-} \longrightarrow \mathrm{SO}_{4}^{2-}+\mathrm{OH}^{-} \\
& 2 \mathrm{~S}_{2} \mathrm{O}_{8}^{2-}+2 \mathrm{H}_{2} \mathrm{O} \longrightarrow 4 \mathrm{HSO}_{4}^{-}+\mathrm{O}_{2}^{-} \\
& \mathrm{HSO}_{4}^{-} \longrightarrow \mathrm{SO}_{4}^{2-}+\mathrm{H}^{+}
\end{aligned}
$$

3.3.4. Effect of Temperature. Figure 6 shows NOR degradation in the PS (control experiments) and nZVI/PS systems under different temperatures. The results indicated that the higher temperatures favored degradation of NOR. The degradation efficiency of NOR increased from $76.9 \%$ to $99.8 \%$ as the temperature increased from 15 to $45^{\circ} \mathrm{C}$ and the corresponding kinetic rate constants also increased from 0.211 to $1.202 \mathrm{~min}^{-1}$. As expected, the degradation efficiency increased owing to the increasing production of $\mathrm{SO}_{4}{ }^{--}$at higher temperatures [34]. The higher temperature could also increase the frequency of molecular collisions and accelerated the removal rate of NOR as a result. Considering the possibility of NOR degradation in thermally activated PS [16], control experiments were performed. The results (Fig. S3) revealed that an insignificant amount of NOR was removed $(<15 \%)$ in the PS system after $30 \mathrm{~min}$, thus indicating the inefficiency in terms of activating PS. It had been reported that PS can be effectively activated only when the temperature is over $50^{\circ} \mathrm{C}$, which also supported our findings [57].
The activation energy of NOR degradation could be calculated by the Arrhenius equation:

$$
\ln k=-\frac{E_{\mathrm{a}}}{R T}+\ln A,
$$

where $k$ was the rate constant, $E_{\mathrm{a}}$ was the Arrhenius activation energy $(\mathrm{kJ} / \mathrm{mol}), A$ was the frequency factor, $R$ was the universal gas constant $(8.314 \mathrm{~J} /(\mathrm{mol} \mathrm{K}))$, and $T$ was the absolute temperature. The $E_{\mathrm{a}}$ was calculated as $42.94 \mathrm{~kJ} / \mathrm{mol}$, which indicated that the degradation of NOR could be regarded as a surface-controlled reaction [58]. It could be concluded that the degradation of NOR in the nZVI/PS system could be easily achieved owing to its relatively low activation energy [59].

3.4. Degradation Mechanism of NOR. As mentioned previously, $\mathrm{OH}^{*}$ could be generated from $\mathrm{SO}_{4}{ }^{--}$through different ways (Equations (13) and (14)); therefore, it was necessary to explore the potential effect of $\mathrm{OH}$ on the degradation of NOR owing to its strong oxidation ability. The radical quenching experiments were carried out to evaluate the contribution of different radicals in the degradation process. $\mathrm{MeOH}$ was regarded as an effective scavenger for both $\mathrm{SO}_{4}^{--}$and $\mathrm{OH}^{-}\left(k_{\mathrm{SO} 4--}=0.9-1.3 \times 10^{7} \mathrm{M}^{-1} \mathrm{~S}^{-1}, k_{\mathrm{OH} .}=\right.$ $\left.8.0-10 \times 10^{8} \mathrm{M}^{-1} \mathrm{~S}^{-1}\right)$, and TBA was a strong quenching agent selective for $\mathrm{OH} \quad\left(k_{\mathrm{OH}}=3.8-7.6 \times 10^{8} \mathrm{M}^{-1} \mathrm{~S}^{-1}\right.$, $\left.k_{\text {SO4-- }}=4.0-9.1 \times 10^{5} \mathrm{M}^{-1} \mathrm{~S}^{-1}\right) \quad[57,60]$. Therefore, $\mathrm{MeOH}$ and TBA were employed as the quenching agents. However, the reaction rate constants of the reaction between NOR and radicals were very high $\left(k=10^{7}-10^{9} \mathrm{M}^{-1} \mathrm{~s}^{-1}\right.$ for $\mathrm{SO}_{4}{ }^{--}$and $1 \times 10^{9} \mathrm{M}^{-1} \mathrm{~s}^{-1}$ for $\mathrm{OH}$ ) [57]. To ensure that the scavengers had priority in consuming radicals, an overwhelming concentration of $\mathrm{MeOH}$ and TBA was used in the quenching study. 


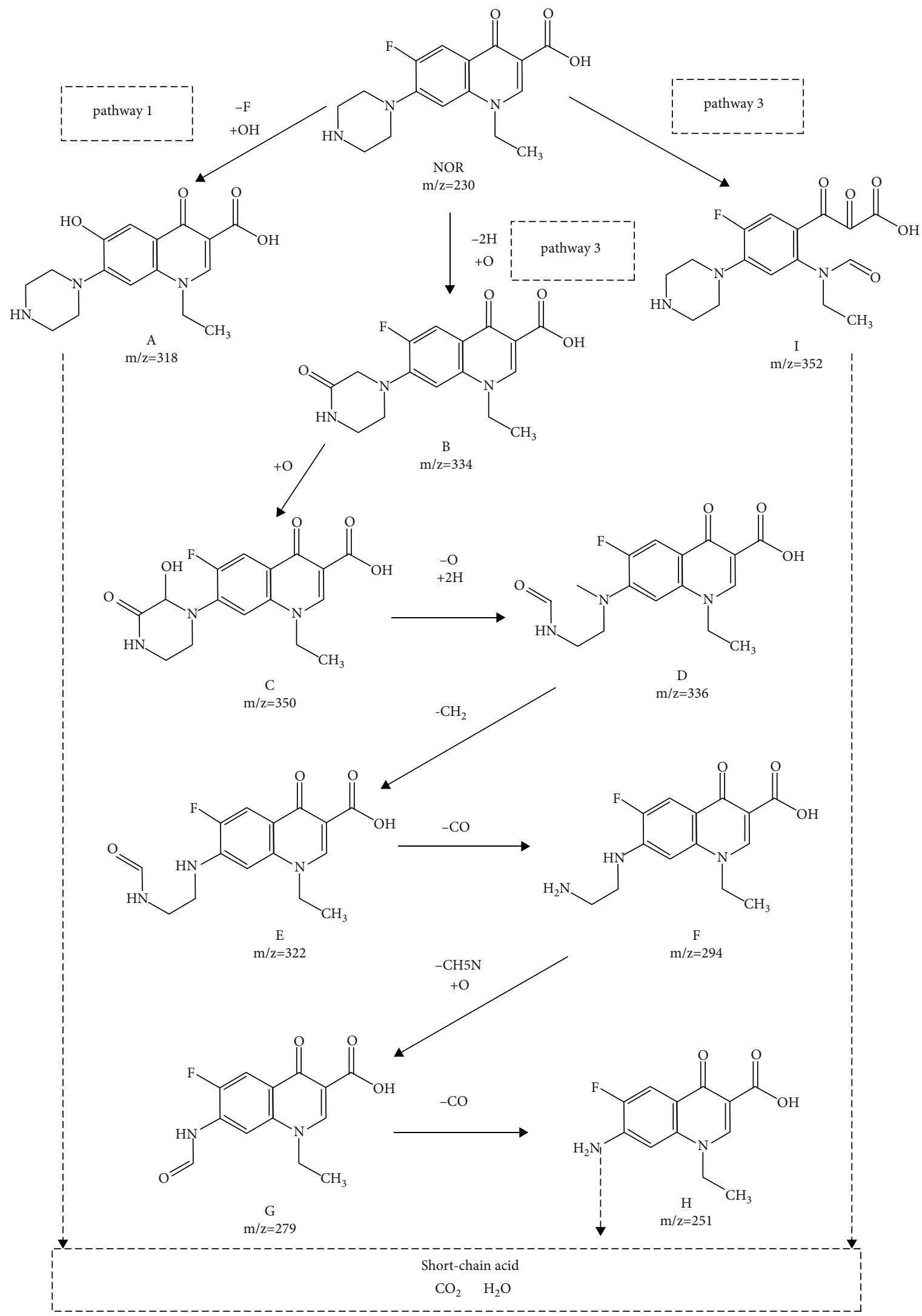

FIgURE 8: Proposed degradation pathways of NOR in the nZVI/PS system. 
As depicted in Figure 7(a), the addition of scavengers had a different inhibiting effect on NOR degradation. The degradation efficiency decreased from $93.8 \%$ to $64.3 \%$ and $46.1 \%$ with $1 \mathrm{M} \mathrm{MeOH}$ and TBA, respectively. With increases in $\mathrm{MeOH}$ and TBA concentrations to $2 \mathrm{M}$, the degradation efficiency further decreased to $52.8 \%$ and $38.3 \%$, respectively. The results demonstrated that both $\mathrm{SO}_{4}{ }^{-}$and $\mathrm{OH}$ were responsible for NOR degradation in the nZVI/PS system $[34,61]$. The inhibiting effect of TBA was greater than that of $\mathrm{MeOH}$, indicating that $\mathrm{OH}^{-}$played a more important role in the process. These results were also consistent with previous reports [62-64].

EPR analysis coupled with DMPO as the radical spin trap was conducted to identify the generation of free radicals. As shown in Figure $7(\mathrm{~b})$, the signals of $\mathrm{DMPO}-\mathrm{SO}_{4}^{--}$and DMPO-OH were recognized by their hyperfine splitting peaks (six lines, 1:1:1:1:1:1 for DMPO-SO ${ }_{4}^{-{ }^{-}}$and four lines, $1: 2: 2: 1$ for DMPO-OH), which were direct evidences that $\mathrm{SO}_{4}{ }^{--}$and $\mathrm{OH}^{-}$coexisted in the nZVI/PS system $[29,62]$. However, the peaks of these radicals could not be identified in the PS system owing to their low concentrations, confirming that PS could not be effectively activated at $25^{\circ} \mathrm{C}$ to generate sufficient radicals. The signal of $\mathrm{DMPO}-\mathrm{OH}^{-}$was stronger than that of DMPO-SO ${ }_{4}^{--}$in the nZVI/PS system, revealing that more $\mathrm{OH}^{-}$was generated in the degradation process [29]. The results were highly consistent with the results of quenching experiments.

Based on the above analyses, the possible mechanism for NOR degradation by the nZVI/PS system was proposed. First, $\mathrm{Fe}^{2+}$ was formed on the surface of nZVI owing to the corrosion of $\mathrm{Fe}^{0}$. Second, PS was activated by $\mathrm{Fe}^{2+}$, and the highly reactive radicals $\mathrm{SO}_{4}{ }^{-} / \mathrm{OH}$ were generated continuously. Finally, NOR was attacked by $\mathrm{SO}_{4}{ }^{-} / \mathrm{OH}$ and transformed into its intermediates with a series of reactions. Meanwhile, a quantity of NOR was mineralized to $\mathrm{CO}_{2}$ and $\mathrm{H}_{2} \mathrm{O}$.

3.5. Possible Pathways of NOR Degradation. The intermediate products of NOR degradation in the nZVI/PS system were analyzed by LC-MS, and the MS spectra were compared with the results of previous reports $[29,57]$. Except for NOR, eight intermediates or degradation products were identified, and their structures are listed in the Fig. S3. The structure of the piperazinyl ring and nalidixic rings, which seem to be easily attacked by free radicals, was relatively unstable according to the results of a quantitative calculation [41]. Moreover, the standard redox potentials of $\mathrm{SO}_{4}{ }^{--}$and $\mathrm{OH}$ $(2.60 \mathrm{~V}$ and $2.80 \mathrm{~V})$ were higher than those of the activation energies of hydroxylation on the piperazinyl ring, furthermore, the defluorination and hydroxylation reactions on the quinolone group of $\mathrm{NOR}(1.55-2.35 \mathrm{eV})$ [65]. $\mathrm{SO}_{4}{ }^{-}$ tended to attack the electron-rich sites via electron transfer, and $\mathrm{OH}^{-}$was selective for hydrogen abstraction or addition reaction [66]. On the basis of the structure of the degradation products and literature reports [53, 67], three possible degradation pathways of NOR are proposed in Figure 8: pathway 1: defluorination. The C-F bond was directly attacked by radicals due to the nucleophilicity of the fluorine atom, and F was replaced by the hydroxyl group, which yielded com- pound A [11]; pathway 2: piperazine ring opening and cleavage. The reaction was initiated by carbonylation and hydroxylation of NOR, and compounds B and C were successively generated [68]. Then, cleavage of the piperazine ring could occur during the oxidation of compound $C$ followed by structural rearrangement, producing compound $\mathrm{D}$. Compound $\mathrm{D}$ could lose $-\mathrm{CH}_{2}$ and $-\mathrm{CO}$ groups successfully to form compounds $\mathrm{E}$ and $\mathrm{F}$; compound $\mathrm{F}$ could continue to lose $-\mathrm{C}_{2} \mathrm{H}_{5} \mathrm{~N}$ to yield compound $\mathrm{G}$, which finally underwent decarbonylation to form compound $\mathrm{H}$; and pathway 3 : quinolone group transformation. The quinolone moieties were attacked by radicals at the $\mathrm{C}=\mathrm{C}$ bond adjacent to the carboxylic acid group; thus, compound I was generated. Several studies have reported the formation of short-chain organic compounds in the degradation of NOR by AOPs $[52,53]$. Finally, some of the transformation products were further mineralized to $\mathrm{CO}_{2}$ and $\mathrm{H}_{2} \mathrm{O}$.

\section{Conclusions}

This study provided a simple and effective method for the removal of NOR in aqueous solutions by using nZVI as the catalyst to activate PS. The key findings are as follows:

(1) nZVI demonstrated excellent catalytic activity, and a high removal efficiency (93.8\%) of NOR was achieved in the nZVI/PS system

(2) NOR degradation was significantly influenced by nZVI dosage, PS concentration, initial $\mathrm{pH}$, and temperature

(3) Both $\mathrm{SO}_{4}{ }^{--}$and $\mathrm{OH}^{-}$were the dominant radical species based on the results of quenching experiments and EPR analysis, while $\mathrm{OH}^{\prime}$ played a more important role

(4) The intermediates were analyzed, and three degradation pathways including defluorination, piperazinyl ring opening, and quinolone group transformation were proposed

This study suggested that nZVI/PS is a promising pretreatment process for the antibiotic pollution caused by NOR.

\section{Data Availability}

Data Availability Statement The data that support the findings of this study are openly available in "Figshare " at 10 $.6084 / \mathrm{m} 9$. figshare.10269944.v1.

\section{Conflicts of Interest}

The authors declare that they have no conflicts of interest.

\section{Acknowledgments}

This work was financially supported by the National Natural Science Foundation of China (21276182). 


\section{Supplementary Materials}

Figure S1: characterizations of the nZVI. (a) TEM, (b) XRD, (c) XPS analysis. Figure S2: change profiles of TOC and NOR concentration versus time in the nZVI/PS system. Operating conditions: $C_{0}=100 \mathrm{mg} / \mathrm{L}, \mathrm{pH}=7.0, T=25^{\circ} \mathrm{C},[\mathrm{PS}]_{0}=12$ $\mathrm{mM}$, and $\mathrm{nZVI}=0.1 \mathrm{~g} / \mathrm{L}$. Figure $\mathrm{S} 3$ : the degradation efficiency of NOR in the PS system. Operating conditions: $C_{0}=100 \mathrm{mg} / \mathrm{L}, \mathrm{pH}=7.0$, and $[\mathrm{PS}]_{0}=12 \mathrm{mM}$. Figure S4: MS spectra of degradation products of NOR in the nZVI-BC/PS system. Graph abstract: the whole process of NOR degradation in the nZVI/PS system. The picture demonstrated the corrosion of nZVI, the activation of PS, and the potential pathway in the process. (Supplementary Materials)

\section{References}

[1] K. Helwig, C. Hunter, M. McNaughtan, J. Roberts, and O. Pahl, "Ranking prescribed pharmaceuticals in terms of environmental risk: inclusion of hospital data and the importance of regular review," Environmental Toxicology and Chemistry, vol. 35, no. 4, pp. 1043-1050, 2016.

[2] L. Zhu, B. Santiago-Schübel, H. Xiao, H. Hollert, and S. Kueppers, "Electrochemical oxidation of fluoroquinolone antibiotics: mechanism, residual antibacterial activity and toxicity change," Water Research, vol. 102, pp. 52-62, 2016.

[3] M. Huang, T. Zhou, X. Wu, and J. Mao, "Distinguishing homogeneous-heterogeneous degradation of norfloxacin in a photochemical Fenton-like system $\left(\mathrm{Fe}_{3} \mathrm{O}_{4} / \mathrm{UV} /\right.$ oxalate $)$ and the interfacial reaction mechanism," Water Research, vol. 119, pp. 47-56, 2017.

[4] B. Wang, Y.-s. Jiang, F.-y. Li, and D.-y. Yang, "Preparation of biochar by simultaneous carbonization, magnetization and activation for norfloxacin removal in water," Bioresource Technology, vol. 233, pp. 159-165, 2017.

[5] M. J. Ahmed and S. K. Theydan, "Fluoroquinolones antibiotics adsorption onto microporous activated carbon from lignocellulosic biomass by microwave pyrolysis," Journal of the Taiwan Institute of Chemical Engineers, vol. 45, no. 1, pp. 219-226, 2014.

[6] A. Özcan, A. Atılır Özcan, and Y. Demirci, "Evaluation of mineralization kinetics and pathway of norfloxacin removal from water by electro-Fenton treatment," Chemical Engineering Journal, vol. 304, pp. 518-526, 2016.

[7] K. He, E. Hain, A. Timm, M. Tarnowski, and L. Blaney, "Occurrence of antibiotics, estrogenic hormones, and UVfilters in water, sediment, and oyster tissue from the Chesapeake Bay," Science of the Total Environment, vol. 650, Part 2, pp. 3101-3109, 2019.

[8] A. L. Batt, S. Kim, and D. S. Aga, "Comparison of the occurrence of antibiotics in four full-scale wastewater treatment plants with varying designs and operations," Chemosphere, vol. 68, no. 3, pp. 428-435, 2007.

[9] X. Van Doorslaer, J. Dewulf, H. Van Langenhove, and K. Demeestere, "Fluoroquinolone antibiotics: an emerging class of environmental micropollutants," Science of the Total Environment, vol. 500-501, pp. 250-269, 2014.

[10] C. L. Amorim, A. S. Maia, R. B. R. Mesquita et al., "Performance of aerobic granular sludge in a sequencing batch bioreactor exposed to ofloxacin, norfloxacin and ciprofloxacin," Water Research, vol. 50, pp. 101-113, 2014.
[11] H. Guo, T. Ke, N. Gao, Y. Liu, and X. Cheng, "Enhanced degradation of aqueous norfloxacin and enrofloxacin by UVactivated persulfate: kinetics, pathways and deactivation," Chemical Engineering Journal, vol. 316, pp. 471-480, 2017.

[12] X.-f. Tan, Y.-g. Liu, Y.-l. Gu et al., "Biochar-based nanocomposites for the decontamination of wastewater: a review," Bioresource Technology, vol. 212, pp. 318-333, 2016.

[13] C. Pablos, J. Marugán, R. van Grieken, and E. Serrano, "Emerging micropollutant oxidation during disinfection processes using UV-C, UV-C/H2O2, UV-A/TiO2 and UVA/TiO2/H2O2," Water Research, vol. 47, no. 3, pp. 12371245, 2013.

[14] C.-C. Lin and Y.-H. Chen, "Feasibility of using nanoscale zerovalent iron and persulfate to degrade sulfamethazine in aqueous solutions," Separation and Purification Technology, vol. 194, pp. 388-395, 2018.

[15] K.-C. Huang, Z. Zhao, G. E. Hoag, A. Dahmani, and P. A. Block, "Degradation of volatile organic compounds with thermally activated persulfate oxidation," Chemosphere, vol. 61, no. 4, pp. 551-560, 2005.

[16] J. Lu, J. Wu, Y. Ji, and D. Kong, "Transformation of bromide in thermo activated persulfate oxidation processes," Water Research, vol. 78, pp. 1-8, 2015.

[17] J.-Y. Fang and C. Shang, "Bromate formation from bromide oxidation by the UV/persulfate process," Environmental Science \& Technology, vol. 46, no. 16, pp. 8976-8983, 2012.

[18] Y. Ji, C. Ferronato, A. Salvador, X. Yang, and J.-M. Chovelon, "Degradation of ciprofloxacin and sulfamethoxazole by ferrous-activated persulfate: implications for remediation of groundwater contaminated by antibiotics," Science of the Total Environment, vol. 472, pp. 800-808, 2014.

[19] B.-T. Zhang, Y. Zhang, Y. Teng, and M. Fan, "Sulfate radical and its application in decontamination technologies," Critical Reviews in Environmental Science and Technology, vol. 45, no. 16, pp. 1756-1800, 2014.

[20] A. Rastogi, S. R. Al-Abed, and D. D. Dionysiou, "Effect of inorganic, synthetic and naturally occurring chelating agents on Fe(II) mediated advanced oxidation of chlorophenols," Water Research, vol. 43, no. 3, pp. 684-694, 2009.

[21] H. Dong, Q. He, G. Zeng et al., "Degradation of trichloroethene by nanoscale zero-valent iron (nZVI) and nZVI activated persulfate in the absence and presence of EDTA," Chemical Engineering Journal, vol. 316, pp. 410-418, 2017.

[22] D. O'Carroll, B. Sleep, M. Krol, H. Boparai, and C. Kocur, "Nanoscale zero valent iron and bimetallic particles for contaminated site remediation," Advances in Water Resources, vol. 51, pp. 104-122, 2013.

[23] X. Zhao, W. Liu, Z. Cai, B. Han, T. Qian, and D. Zhao, “An overview of preparation and applications of stabilized zerovalent iron nanoparticles for soil and groundwater remediation," Water Research, vol. 100, pp. 245-266, 2016.

[24] X. Li, M. Zhou, Y. Pan, and L. Xu, "Pre-magnetized Fe0/persulfate for notably enhanced degradation and dechlorination of 2,4-dichlorophenol," Chemical Engineering Journal, vol. 307, pp. 1092-1104, 2017.

[25] I. Hussain, Y. Zhang, S. Huang, and X. Du, "Degradation of p-chloroaniline by persulfate activated with zero-valent iron," Chemical Engineering Journal, vol. 203, pp. 269-276, 2012.

[26] G. Barzegar, S. Jorfi, V. Zarezade, M. Khatebasreh, F. Mehdipour, and F. Ghanbari, "4-Chlorophenol degradation using ultrasound/peroxymonosulfate/nanoscale zero valent 
iron: reusability, identification of degradation intermediates and potential application for real wastewater," Chemosphere, vol. 201, pp. 370-379, 2018.

[27] H. Luo, Q. Lin, X. Zhang et al., "New insights into the formation and transformation of active species in nZVI/BC activated persulfate in alkaline solutions," Chemical Engineering Journal, vol. 359, pp. 1215-1223, 2019.

[28] C.-C. Lin and S.-T. Hsu, "Performance of nZVI/H2O2 process in degrading polyvinyl alcohol in aqueous solutions," Separation and Purification Technology, vol. 203, pp. 111-116, 2018.

[29] J. Deng, M. Xu, Y. Chen et al., "Highly-efficient removal of norfloxacin with nanoscale zero-valent copper activated persulfate at mild temperature," Chemical Engineering Journal, vol. 366, pp. 491-503, 2019.

[30] X. Cai, Y. Gao, Q. Sun, Z. Chen, M. Megharaj, and R. Naidu, "Removal of co-contaminants $\mathrm{Cu}$ (II) and nitrate from aqueous solution using kaolin-Fe/Ni nanoparticles," Chemical Engineering Journal, vol. 244, pp. 19-26, 2014.

[31] J. Wei, Y. Qian, W. Liu et al., "Effects of particle composition and environmental parameters on catalytic hydrodechlorination of trichloroethylene by nanoscale bimetallic Ni-Fe," Journal of Environmental Sciences, vol. 26, no. 5, pp. 1162-1170, 2014.

[32] T. Phenrat, T. S. T. Le, B. Naknakorn, and G. V. Lowry, "Chemical reduction and oxidation of organic contaminants by nanoscale zerovalent iron," in Nanoscale Zerovalent Iron Particles for Environmental Restoration: From Fundamental Science to Field Scale Engineering Applications, T. Phenrat and G. V. Lowry, Eds., pp. 97-155, Springer International Publishing, 2019.

[33] T. Phenrat and G. Lowry, Nanoscale Zerovalent Iron Particles for Environmental Restoration: From Fundamental Science to Field Scale Engineering Applications, Springer, 2019.

[34] I. Hussain, M. Li, Y. Zhang et al., "Insights into the mechanism of persulfate activation with nZVI/BC nanocomposite for the degradation of nonylphenol," Chemical Engineering Journal, vol. 311, pp. 163-172, 2017.

[35] J. M. Monteagudo, A. Durán, R. González, and A. J. Expósito, "In situ chemical oxidation of carbamazepine solutions using persulfate simultaneously activated by heat energy, UV light, $\mathrm{Fe}^{2+}$ ions, and $\mathrm{H}_{2} \mathrm{O}_{2}$," Applied Catalysis B: Environmental, vol. 176-177, pp. 120-129, 2015.

[36] C. Liang, C.-F. Huang, N. Mohanty, and R. M. Kurakalva, “A rapid spectrophotometric determination of persulfate anion in ISCO," Chemosphere, vol. 73, no. 9, pp. 1540-1543, 2008.

[37] T. Phenrat, N. Saleh, K. Sirk, R. Tilton, and G. Lowry, “Aggregation and sedimentation of aqueous nanoscale zerovalent iron dispersions," Environmental Science \& Technology, vol. 41, no. 1, pp. 284-290, 2007.

[38] Z. Fang, J. Chen, X. Qiu, X. Qiu, W. Cheng, and L. Zhu, “Effective removal of antibiotic metronidazole from water by nanoscale zero- valent iron particles," Desalination, vol. 268, no. $1-3$, pp. $60-67,2011$

[39] P. Li, K. Lin, Z. Fang, and K. Wang, "Enhanced nitrate removal by novel bimetallic Fe/Ni nanoparticles supported on biochar," Journal of Cleaner Production, vol. 151, pp. 21-33, 2017.

[40] J. Wu, Y. Yi, Y. Li, Z. Fang, and E. P. Tsang, "Excellently reactive $\mathrm{Ni} / \mathrm{Fe}$ bimetallic catalyst supported by biochar for the remediation of decabromodiphenyl contaminated soil: reactivity, mechanism, pathways and reducing secondary risks," Journal of Hazardous Materials, vol. 320, pp. 341-349, 2016.
[41] W. Zhang, H. Gao, J. He et al., "Removal of norfloxacin using coupled synthesized nanoscale zero-valent iron (nZVI) with $\mathrm{H}_{2} \mathrm{O}_{2}$ system: optimization of operating conditions and degradation pathway," Separation and Purification Technology, vol. 172, pp. 158-167, 2017.

[42] M. Nie, C. Yan, M. Li, X. Wang, W. Bi, and W. Dong, "Degradation of chloramphenicol by persulfate activated by $\mathrm{Fe} 2+$ and zerovalent iron," Chemical Engineering Journal, vol. 279, pp. 507-515, 2015.

[43] M. A. Al-Shamsi and N. R. Thomson, "Treatment of organic compounds by activated persulfate using nanoscale zerovalent iron," Industrial \& Engineering Chemistry Research, vol. 52, no. 38, pp. 13564-13571, 2013.

[44] L. Chen, X. Zuo, S. Yang, T. Cai, and D. Ding, "Rational design and synthesis of hollow Co3O4@Fe2O3 core-shell nanostructure for the catalytic degradation of norfloxacin by coupling with peroxymonosulfate," Chemical Engineering Journal, vol. 359, pp. 373-384, 2019.

[45] H. Li, J. Wan, Y. Ma, Y. Wang, and M. Huang, "Influence of particle size of zero-valent iron and dissolved silica on the reactivity of activated persulfate for degradation of acid orange 7," Chemical Engineering Journal, vol. 237, pp. 487496, 2014.

[46] C. Cai, Z. Zhang, and H. Zhang, "Electro-assisted heterogeneous activation of persulfate by Fe/SBA-15 for the degradation of Orange II," Journal of Hazardous Materials, vol. 313, pp. 209-218, 2016.

[47] A. Babuponnusami and K. Muthukumar, "Removal of phenol by heterogenous photo electro Fenton-like process using nano-zero valent iron," Separation and Purification Technology, vol. 98, pp. 130-135, 2012.

[48] C. Liang, Z.-S. Wang, and C. J. Bruell, "Influence of $\mathrm{pH}$ on persulfate oxidation of TCE at ambient temperatures," Chemosphere, vol. 66, no. 1, pp. 106-113, 2007.

[49] J. T. Nurmi, P. G. Tratnyek, V. Sarathy et al., "Characterization and properties of metallic iron nanoparticles: spectroscopy, electrochemistry, and kinetics," Environmental Science \& Technology, vol. 39, no. 5, pp. 1221-1230, 2005.

[50] A. Ghauch, G. Ayoub, and S. Naim, "Degradation of sulfamethoxazole by persulfate assisted micrometric $\mathrm{Fe} 0$ in aqueous solution," Chemical Engineering Journal, vol. 228, pp. 1168-1181, 2013.

[51] Q. Wang, Y. Shao, N. Gao et al., "Degradation of alachlor with zero-valent iron activating persulfate oxidation," Journal of the Taiwan Institute of Chemical Engineers, vol. 63, pp. 379-385, 2016.

[52] Y. Wang, D. Tian, W. Chu, M. Li, and X. Lu, "Nanoscaled magnetic $\mathrm{CuFe}_{2} \mathrm{O}_{4}$ as an activator of peroxymonosulfate for the degradation of antibiotics norfloxacin," Separation and Purification Technology, vol. 212, pp. 536-544, 2019.

[53] G. Wang, D. Zhao, F. Kou, Q. Ouyang, J. Chen, and Z. Fang, "Removal of norfloxacin by surface Fenton system $\left(\mathrm{MnFe}_{2} \mathrm{O}_{4} / \mathrm{H}_{2} \mathrm{O}_{2}\right)$ : kinetics, mechanism and degradation pathway," Chemical Engineering Journal, vol. 351, pp. 747-755, 2018.

[54] J. Li, Q. Ji, B. Lai, and D. Yuan, "Degradation of $p$-nitrophenol by $\mathrm{Fe}^{0} / \mathrm{H}_{2} \mathrm{O}_{2} /$ persulfate system: optimization, performance and mechanisms," Journal of the Taiwan Institute of Chemical Engineers, vol. 80, pp. 686-694, 2017.

[55] X. Wei, N. Gao, C. Li, Y. Deng, S. Zhou, and L. Li, "Zero-valent iron (ZVI) activation of persulfate (PS) for oxidation of 
bentazon in water," Chemical Engineering Journal, vol. 285, pp. 660-670, 2016.

[56] E. Hayon, A. Treinin, and J. Wilf, "Electronic spectra, photochemistry, and autoxidation mechanism of the sulfitebisulfite-pyrosulfite systems. SO2-, SO3-, SO4-, and SO5radicals," Journal of the American Chemical Society, vol. 94, no. 1, pp. 47-57, 1972.

[57] D. Ding, C. Liu, Y. Ji et al., "Mechanism insight of degradation of norfloxacin by magnetite nanoparticles activated persulfate: identification of radicals and degradation pathway," Chemical Engineering Journal, vol. 308, pp. 330-339, 2017.

[58] R. Li, X. Jin, M. Megharaj, R. Naidu, and Z. Chen, "Heterogeneous Fenton oxidation of 2,4-dichlorophenol using iron-based nanoparticles and persulfate system," Chemical Engineering Journal, vol. 264, pp. 587-594, 2015.

[59] X.-R. Xu and X.-Z. Li, "Degradation of azo dye Orange G in aqueous solutions by persulfate with ferrous ion," Separation and Purification Technology, vol. 72, no. 1, pp. 105-111, 2010.

[60] J. Yan, L. Han, W. Gao, S. Xue, and M. Chen, "Biochar supported nanoscale zerovalent iron composite used as persulfate activator for removing trichloroethylene," Bioresource Technology, vol. 175, pp. 269-274, 2015.

[61] Y. Wang, S.-y. Chen, X. Yang et al., "Degradation of $2,2^{\prime}, 4,4^{\prime}$-tetrabromodiphenyl ether (BDE-47) by a nano zerovalent iron-activated persulfate process: the effect of metal ions," Chemical Engineering Journal, vol. 317, pp. 613-622, 2017.

[62] G. Peng, T. Li, B. Ai et al., "Highly efficient removal of enrofloxacin by magnetic montmorillonite via adsorption and persulfate oxidation," Chemical Engineering Journal, vol. 360, pp. 1119-1127, 2019.

[63] S. Yuan, P. Liao, and A. N. Alshawabkeh, "Electrolytic manipulation of persulfate reactivity by iron electrodes for trichloroethylene degradation in groundwater," Environmental Science \& Technology, vol. 48, no. 1, pp. 656-663, 2014.

[64] L. W. Matzek and K. E. Carter, "Sustained persulfate activation using solid iron: kinetics and application to ciprofloxacin degradation," Chemical Engineering Journal, vol. 307, pp. 650-660, 2017.

[65] H. Li, J. Chen, H. Hou et al., "Sustained molecular oxygen activation by solid iron doped silicon carbide under microwave irradiation: mechanism and application to norfloxacin degradation," Water Research, vol. 126, pp. 274-284, 2017.

[66] H. Li, J. Wan, Y. Ma, and Y. Wang, "Reaction pathway and oxidation mechanisms of dibutyl phthalate by persulfate activated with zero-valent iron," Science of the Total Environment, vol. 562, pp. 889-897, 2016.

[67] T. Zhou, X. Zou, X. Wu, J. Mao, and J. Wang, "Synergistic degradation of antibiotic norfloxacin in a novel heterogeneous sonochemical $\mathrm{Fe} 0 /$ tetraphosphate Fenton-like system," Ultrasonics Sonochemistry, vol. 37, pp. 320-327, 2017.

[68] H. Yang, L. Mei, P. Wang et al., "Photocatalytic degradation of norfloxacin on different $\mathrm{TiO} 2-\mathrm{Xpolymorphs}$ under visible light in water," RSC Advances, vol. 7, no. 72, pp. 4572145732, 2017. 